\title{
A Importância da Produção Vegetal para o Século XXI
}

Nos primórdios, quando o homem iniciou a domesticação das espécies, há cerca de 12.000 anos, selecionando os vegetais mais desejáveis, de maneira involuntária, tal ação culminou com o surgimento da agricultura. Dessa forma, o homem passou a se relacionar em grupos e, então, houve o surgimento das civilizações, considerado um dos maiores avanços da humanidade. Entretanto, a Revolução Industrial e a Revolução Verde trouxeram benefícios inimagináveis para a sociedade e, aliados a este, diversos problemas, causados pelo desenvolvimento acelerado. $\mathrm{O}$ maior salto observado pela sociedade moderna ocorreu nas últimas décadas com obtenção de plantas geneticamente modificadas (OGM). A engenharia genética quebra as barreiras das espécies e o que, teoricamente seria impossível de ser realizado, passa a ser plausível, ou seja, inserir ou suprimir um ou mais genes de qualquer ser vivo, com qualidades inéditas na natureza.

Mesmo com a capacidade de alterar o genoma vegetal, visando ao maior potencial produtivo e ao manejo sustentável do sistema agrícola, a produtividade das espécies está em patamares altíssimos, quase que impossíveis de ser acrescidos. Além disso, a utilização de transgênicos não reduz a emissão de gases danosos ao efeito estufa e o problema continuaria a se perpetuar durante os anos. E, devido às mudanças climáticas ocasionadas pelo aquecimento global, a produtividade das espécies tende a permanecer estável, com risco de queda, se as plantas não apresentarem características para suportar tal mudança a tempo de possíveis alterações mais drásticas. Independentemente de suas origens, as mudanças climáticas produzem impactos que poderão ter amplos reflexos no meio ambiente. Atualmente, essas mudanças vêm afetando os padrões regionais de precipitação e de evapotranspiração, o que tem repercutido em todo regime hidrológico, biológico e agrícola, amplamente discutido por diversos pesquisadores.
Recentemente, o mundo, aterrorizado com as possíveis consequências, gerou uma enormidade de informações sobre o desenvolvimento sustentável e, então, surgiu o termo "Agricultura de Baixo Carbono ABC". No Brasil, o programa ABC tem como o objetivo de estimular as práticas mais sustentáveis por meio de atividades específicas como o plantio direto na palha e recuperação de áreas degradadas, com o intuito de reduzir o dano já causado pela emissão de gases.

Nas últimas décadas, têm-se intensificado os debates sobre o aquecimento global e as mudanças climáticas, havendo quase um consenso entre os cientistas de que a intensificação do efeito estufa planetário encontra-se, principalmente, relacionada ao padrão de produção e ao consumo da sociedade moderna. As mudanças climáticas, registradas nas últimas décadas, vêm comprometendo o funcionamento dos ecossistemas e, também, os agroecossistemas, alterando a oferta de serviços ambientais, consequentemente, reduzindo a disponibilidade de água, boas fertilidades e a conservação do solo, bem como a biodiversidade como um todo. Ao mesmo tempo em que contribuirá para o aumento da incidência de pragas/doenças e na redução de áreas propícias à produção agrícola. Além das consequências, supracitadas, alterações nos ciclos hidrológicos, secas ou inundações; aumento da frequência e intensidade de ciclones e furacões; contaminação de lençóis freáticos com água salgada; desertificação; perda de biodiversidade; intensificação de fenômenos meteorológicos danosos; inundação de zonas costeiras e até o desaparecimento de ilhas.

Os mais importantes estudos sobre esse tema mostram que as regiões tropicais, mesmo não sendo as maiores responsáveis pelo aquecimento global, serão muito mais afetadas pelas mudanças climáticas que as temperadas. O International Food Policy Research Institute (IFPRI Instituto Internacional de Pesquisa de Política Alimentar) fez um estudo com base em diversos modelos climáticos e o resultado converge para uma preocupante direção 
de declínio geral, com relação ao ritmo de aumento da produção agropecuária. Os resultados ainda podem ser mais impressionantes, de acordo com 23 modelos climáticos globais, há $90 \%$ de chance de que as temperaturas dos trópicos e dos subtrópicos, no final do século XXI, excedam as maiores temperaturas já registradas entre 1900 e 2006 . Entre 1861 e 2000, a temperatura média global aumentou $0,6^{\circ} \mathrm{C}$, sendo que as precipitações pluviométricas foram alteradas com chuvas mais torrenciais e o fenômeno El Niño tem se tornado mais frequente, persistente e intenso.

Os principais gases, oriundos de atividades antrópicas, que têm atuado na intensificação do efeito estufa, são o metano, o ozônio, o óxido nitroso $\left(\mathrm{O}_{3}\right)$, os CFC's (Clorofluorcarbonos) e em maior proporção dióxido de carbono $\left(\mathrm{CO}_{2}\right)$, responsável por $60 \%$ das consequências detectadas. O desenvolvimento sustentável tem como principal fundamento equilibrar o desenvolvimento econômico com sustentabilidade ambiental, visando à perfeita harmonia entre o meio ambiente e o consumo. Ainda são poucos os estudos sobre as respostas no metabolismo de carbono e na produtividade de plantas agrícolas ao aumento da concentração de $\mathrm{CO}_{2}$ e $\mathrm{O}_{3}$ no campo, em clima tropical, no Brasil. É importante salientar que as respostas fisiológicas às diferentes condições ambientais são muito variáveis, em função do genótipo, ambiente e sua interação fenotípica. Entretanto, encontrar o genótipo com melhor desempenho sob tais condições, não seria uma tarefa fácil e, mesmo que fossem encontrados, os testes e os métodos de medições não trariam certezas e, no máximo, possíveis soluções.

$\mathrm{O}$ acréscimo de $1^{\circ} \mathrm{C}$ na temperatura provoca um aumento de $61,6 \%$ para $85,9 \%$ nas áreas inaptas para o cafeeiro da espécie Coffea arábica, com a elevação de mais $2{ }^{\circ} \mathrm{C}, 99 \%$ do Estado de Goiás passa à condição de inapto, inclusive para o café irrigado. Em função das temperaturas elevadas, a irrigação aparece como regulador térmico, evitando, assim, o abortamento das flores. A dinâmica no processo de surgimento de áreas com baixo e médio risco climático, na porção mais ao leste do Nordeste Brasileiro, pode estar associada à influência dos sistemas atmosféricos, que atuam sobre a região. Portanto, é possível inferir que o aumento de temperatura média do ar, como sendo um fator limitante ao cultivo do algodão, mesmo diante do aumento da oferta hídrica. Resultados semelhantes foram obtidos ao se analisar o cultivo do feijão caupi no Estado da Paraíba. Os cenários climáticos futuros implicam redução média de $31 \%$ na produção nacional de grãos de trigo, sendo os efeitos mais depressivos projetados para a região centrosul, especialmente a partir de 2030.

Os impactos das mudanças climáticas, na agricultura brasileira sobre as plantações de soja, milho, feijão, café e arroz, num futuro bem próximo, reduziram a produção, tais como as áreas plantadas, sendo que a soja seria a cultura mais afetada, seguida pelo café. As exportações brasileiras de soja contribuem para a captação de moedas estrangeiras e equilibram a economia nacional. Por outro lado, é possível melhorar as plantas para suportar os diferentes estresses relatados. Neste caso, plantas capazes de obter mais água ou que tenham maior eficiência no seu uso, resistirão melhor à elevação de temperaturas, secas e, até mesmo, à salinidade, por meio de estratégias como redução da área foliar; deposição de ceras sobre a folha; abscisão de folhas e fechamento de estômatos; acentuado crescimento de raízes por modificações, ou por alterações genéticas e morfofisiológicas, evitando, assim, altas perdas de produtividade.

A utilização de plantas transgênicas, tolerantes aos diferentes estresses citados, já estão sendo testadas. Entre os genes avaliados estão aqueles envolvidos com sinalização; controle de transcrição; proteção das membranas e proteínas e a eliminação dos radicais livres e compostos tóxicos. Recentemente, a investigação sobre os mecanismos moleculares da resposta ao estresse começou a dar frutos e, em paralelo, a modificação genética de tolerância ao estresse também tem mostrado resultados promissores que podem trazer benefícios às plantas agrícolas e ecologicamente importantes em um curto prazo de tempo.

Durante reunião do IPCC, a possibilidade de se utilizar práticas agrícolas conservacionistas como o sistema plantio direto para mitigar o aumento de $\mathrm{CO}_{2}$ na atmosfera, pelo sequestro de carbono pelo solo, obteve consenso internacional. A ideia contida no consenso foi que, promovendo-se a adoção de práticas agrícolas, visando à conservação do solo, seria possível não apenas aumentar a produtividade agrícola como, também, transformar os solos agrícolas em drenos ou sumidouros de $\mathrm{CO}_{2}$ atmosférico. 
Logo, para as empresas, a questão ambiental deixou de ser um problema, para se tornar parte de uma solução maior, a credibilidade da empresa junto à sociedade, mediante qualidade e competitividade de seus produtos. A introdução de novos conceitos como certificação ambiental, atuação responsável e gestão ambiental tende a modificar a postura que marcava, até recentemente, o relacionamento entre as empresas, de um lado, e os órgãos de fiscalização e as ONG's, atuantes na questão ambiental, do outro. Dessa forma, multas vão sendo substituídas por maiores lucratividade e, como beneficio, a empresa ganha com a imagem da credibilidade junto aos consumidores.

Uma das principais estratégias do MAPA (Ministério da Agricultura, Pecuária e Abastecimento) para implementar o Plano $\mathrm{ABC}$, é o envolvimento dos Estados, por meio da integração da Política Nacional de Mudança Climática com os planos estaduais de redução da emissão, mediante Grupos Gestores Estaduais (GGE). Esta integração é justificada pelo pressuposto de que os "estados" possuem conhecimento mais aprofundado sobre a realidade local, considerando-se as fragilidades e oportunidades em cada situação. Em cada etapa do programa do Programa ABC, o produtor se propor a adotar de uma série de ações, como por exemplo, fortalecimento das organizações de assistência técnica e extensão rural; capacitação e informação; estratégias de transferência de tecnologia, tais como, dias de campo, palestras, seminários, workshops, na implantação de Unidades de Referência Tecnológica (URTs), além de campanhas de divulgação e chamadas públicas para contratação de serviços de Assistência Técnica e Extensão Rural.

Por exemplo, para fins de raciocínio, se as Reservas Legais e APPs previstas no Código Florestal brasileiro tiverem uma área total de 100 milhões de hectares e os donos receberem apenas R\$ 200 por hectare por ano, para não desmatar essas áreas, o total anual seria de $\mathrm{R} \$$ 20 bilhões, sendo que o Programa Bolsa Família custa R \$ 15 bilhões por ano. Neste caso, seria possível o governo gastar mais com pagamentos por serviços ambientais do que com Bolsa Família?

O Banco Mundial estima que o Brasil precisaria de R\$ 34,2 bilhões, por ano, para reduzir as emissões de carbono. Já outros pesquisadores estimam que seriam necessários cerca de $\mathrm{R} \$ 20$ bilhões para manter os produtores aliados ao programa. Denotando que não seria impossível, entretanto, políticas econômicas deveriam ser revisadas e, assim, sanar grande parte do problema.

Dessa forma, o combate ao aquecimento global deve ser compatível com o crescimento econômico sustentável e com o combate à fome, levando-se em consideração o manejo e adequação da cultura ao sistema de sequestro de carbono. E, então, ocorrerá a diminuição de efeitos danosos causados pelo efeito estufa e políticas de desenvolvimento sustentável, devem, sim, estabelecerem-se e, ainda, gerarem novas diretrizes de controle de danos. Denotando-se que, os pesquisadores da área de produção vegetal têm papel importante no futuro da sociedade moderna, desde a geração de cultivares capazes de enfrentar alterações climáticas diferentes a descoberta de genes que contribuíram para a sobrevivência das espécies, sendo estas relacionadas ou não.

\section{Fabrício Rodrigues*}

Pesquisador do Programa de Pós-Graduação em Produção Vegetal, da Universidade Estadual de Goiás. Rodovia GO-330, Km 241, Anel Viário, Ipamerí-GO, CEP: 75780-000, Brasil.

* e-mail: fabriciorods@yahoo.com.br 